\title{
CROINTERVENT 2020
}

\section{Poštovani kolegice i kolege, dragi prijatelji,}

zadovoljstvo nam je pozvati vas na 8 . sastanak Radne skupine za invazivnu i intervencijsku kardiologiju Hrvatske udruge kardioloških medicinskih sestara, koji će se održati 21. ožujka u vrijeme 9. nacionalnog kongresa o intervencijskoj kardiologiji s međunarodnim sudjelovanjem, u Zagrebu, u hotelu Westin.

Sastanak je primarno dizajniran za medicinske sestre i srodne profesije u invazivnoj kardiologiji, ali i za medicinske sestre s kardioloških odjela i kardioloških intenzivnih jedinica.

Svrha je ove godine prikazati uvid u napredak i razvoj ostvaren u posljednje dvije godine od zadnjeg sastanka. Teme će uključivati novosti u kompleksnim procedurama i nove slikovne metode. Posebna će pozornost biti posvećena problemima u funkcioniranju PCI mreža i specifičnim savjetima kako ostvariti daljnja poboljšanja.

Ovaj sastanak obećava poticajnu raspravu između medicinskih sestara i srodnih profesija, ali i pružanje mentorstva mlađim kolegicama i kolegama.

Uime Hrvatske udruge kardioloških medicinskih sestara i organizacijskog odbora veselimo se i želimo vam dobrodošlicu u Zagreb na Crointervent 2020.

S poštovanjem,

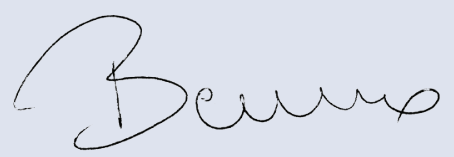

Ivica Benko, dipl. med. techn., ECDSAP /

Ivica Benko, RN, BSN, MSN, ECDSAP

Predsjednik Radne skupine za invazivnu i intervencijsku kardiologiju Hrvatske udruge kardioloških medicinskih sestara / President of the Working Group for Invasive and Interventional Cardiology of the CACN

\section{Dear Friends and Colleagues!}

It is our pleasure to invite you to the $8^{\text {th }}$ Meeting of the Working Group for Invasive and Interventional Cardiology of the Croatian Association of Cardiology Nurses (CACN) that will be held on March 21, during the $9^{\text {th }}$ Conference on Interventional Cardiology with international participation in Hotel Westin in Zagreb, Croatia.

The meeting is designed primarily for cardiology nurses and associated professions in invasive cardiology, but also for nurses from cardiology departments and coronary care units.

This year, our aim is to provide insights into the progress and development that took place over the two years since the last meeting. Topics will include novelties in complex procedures and new imaging techniques. Particular attention will be given to PCI network issues and specific tips on how to make further improvements.

This meeting promises to stimulate discussion among nurses and associated professionals and to provide mentorship to our young colleagues.

On behalf of the CACN and the organizing committee, we look forward to welcoming you to Zagreb for CROINTERVENT 2020.

Sincerely yours,

PREDSJEDNICI 8. SASTANKA / PRESIDENTS OF THE $8^{\text {th }}$ MEETING

Marija Matoš, Ivica Benko

ORGANIZACIJSKI ODBOR / ORGANIZING COMMITTEE

A. Ljubas • J. Daskijević • I. Ferjančić • M. Popić • M. Klasan • A. Kelecević M. Budetić • Z. Puljas

K. Librenjak • B. Šego • S. Škifić • A. Miljas • A. Vujičić • R. Valenčak • R. Višnjovski • M. Čelković • B. Koren

RECEIVED: February 24, 2020

E-MAIL: ivica.benko@kbcsm.hr | CITATION: Cardiol Croat. 2020;15(3-4):60. | https://doi.org/10.15836/ccar2020.60 ORCID: Ivica Benko, https://orcid.org/0000-0002-1878-0880 